\title{
Quality indicators of tank milk in different production systems of tropical regions
}

\section{Indicadores de qualidade do leite de tanque em diferentes sistemas de produção na região tropical}

\author{
Paula Priscilla Liberato da Escóssia Campos ${ }^{1}$; \\ Adriano Henrique do Nascimento Rangel'2; Luis Henrique Fernandes Borba ${ }^{2}$; \\ Stela Antas Urbano ${ }^{3 *}$; Luciano Patto Novaes²; José Geraldo Bezerra Galvão Júnior ${ }^{4}$; \\ Danielle Cavalcanti Sales ${ }^{1}$; Emerson Moreira de Aguiar $^{2}$
}

\begin{abstract}
Research was conducted in eight commercial herds located in the state of Rio Grande do Norte, Brazil. Properties were classified according to the production system, the seasons were divided into four and the genetic groups into six. Milk samples from morning milking were collected monthly, directly from a cooling tank. Protein, fat, lactose, total solids, casein, urea nitrogen concentrations/levels, somatic cell count (SCC) and total bacterial count (TBC) were determined. For milk composition, the detected results were satisfactory and met the requirements of Normative Ruling 62, but the averages for SCC and $\mathrm{TBC}$ were above the recommended limit. All variables, with the exception of casein from total protein were influenced $(\mathrm{P}<0.05)$ by the production system used in the production unit. A lower fat content was recorded in 2010 compared to 2011. For the seasons, all the constituents of milk had lower values in drier season (seasons 3 and 4), with the exception of casein; SCC and TBC had higher values in periods 1 and 2, which are considered rainy periods. There was variation in the chemical composition of milk according to the genotypes. Milk chemical composition met the legal and market requirements, with a positive emphasis on specialized production systems. The variations over the year and according to the genetic group of the herd are also significant and should be taken into account in the search for improvements. As for the hygiene and health aspects of milk, the results portray the need for a greater focus by the entities involved in the sector, as well as the producers, on the viability of an adequacy program and monitoring of management practices related to this criterion.

Key words: Dairy cattle. Milk composition. Somatic cell count. Mastitis. Hygienic milking.
\end{abstract}

\section{Resumo}

A pesquisa foi conduzida em oito rebanhos comerciais situados no estado do Rio Grande do Norte, Brasil. As propriedades foram classificadas quanto ao sistema de produção, as estações do ano foram divididas em quatro e os grupamentos genéticos em seis. Foram coletadas, mensalmente, diretamente

\footnotetext{
${ }^{1}$ Zootecnistas, Mestres, Universidade Federal do Rio Grande do Norte, UFRN, Natal, RN, Brasil. E-mail: paulinhaescossia@ hotmail.com,danicsales@hotmail.com

2 Profs., UFRN, Natal, RN, Brasil.E-mail: adrianohrangel@yahoo.com.br; lborba99@yahoo.com; lpn@ufrnet.br; emersonaguiar@ ufrnet.br

3 Zootecnista, Dr ${ }^{\text {a }}$, Bolsista PNPD/CAPES/UFRN, Natal, RN, Brasil. E-mail: stela_antas@yahoo.com.br

${ }^{4}$ Zootecnista, Prof., M.e, Instituto Federal de Educação, Ciência e Tecnologia do Rio Grande do Norte, IFRN, Campus Ipanguaçu, Ipanguaçu, RN, Brasil. E-mail: geracari@yahoo.com.br

* Author for correspondence
} 
do tanque de resfriamento, amostras de leite na ordenha da manhã. Foram determinados os teores de proteína, gordura, lactose, sólidos totais, caseína, as concentrações de nitrogênio ureico, a contagem de células somáticas (CCS) e a contagem bacteriana total (CBT). Para a composição do leite, os resultados detectados foram satisfatórios e atenderam às exigências previstas na Instrução Normativa 62, mas as médias obtidas para CCS e CBT estão acima do limite recomendado. Todas as variáveis analisadas, com exceção da caseína da proteína total, foram influenciadas $(\mathrm{P}<0,05)$ pelo sistema de produção utilizado na unidade produtiva. Verificou- se menor teor de gordura em 2010, quando comparado a 2011. Para as estações do ano, com exceção da caseína, todos os constituintes do leite apresentaram menores valores na época mais seca (estações 3 e 4), já a CCS e CBT apresentaram maiores valores nas épocas 1 e 2, que são considerados períodos de chuva. Verificou-se variação na composição química do leite de acordo com os genótipos estudados. A composição química do leite atende às exigências legais e de mercado, com destaque positivo para os sistemas de produção especializados. As variações ao longo do ano e de acordo com o grupo genético do rebanho são também significantes, devendo ser levadas em consideração na busca por melhorias. Quanto ao aspecto higiênico-sanitário do leite, os resultados retratam a necessidade de um enfoque maior das entidades envolvidas no setor, bem como dos produtores, na viabilização de um programa de adequação e acompanhamento das práticas de manejo relacionados a este critério.

Palavras-chave: Bovinocultura de leite. Composição do leite. Contagem de células somáticas. Mastite. Ordenha higiênica.

\section{Introduction}

The demand for quality that characterizes the modern consumer market has motivated the dairy industry to implement payment programs that consider the quality of milk (MARTINS et al., 2008). Therefore, some indicators are used to mark the price to be paid for the milk, among those which stand out being somatic cell count (SCC), total bacterial count (TBC) (TAKAHASHI et al., 2012) and the percentages of protein and fat (ROMA JÚNIOR et al., 2009).

The large territory and the different socioeconomic, cultural and climatic conditions of soil in Brazil induce a diversity of production systems for dairy production. Still, the fact that dairy cattle is present in over $80 \%$ of Brazilian municipalities (OLIVEIRA et al., 2007) restates the dispersion of this activity across very heterogeneous agricultural establishments (MAIA et al., 2013), thereby justifying the studies focused on this theme.

According to Andrade et al. (2014), the diet fed to the animals and climatic factors have an influence on the desirable pattern of milk constituents. However, it is speculated that the dynamic character inherent in the production environment can also have a direct influence on the composition and quality of milk produced, as well as time of year, environmental variation, lactation stage, produced volume of milk and storage characteristics (TAKAHASHI et al., 2012). Thus, the objective was to evaluate the chemical composition and sanitary quality of milk produced in different production systems, years, seasons and genotypes.

\section{Material and Methods}

\section{Study site and herds}

The study was conducted during the period January 2010 to March 2012 in eight commercial herds located in the Agreste region of Rio Grande do Norte state, Brazil. The region is characterized by a tropical rainy Aw climate with dry and rainy seasons in the Köppen-Geiger climatic classification. Rains occur between the months of February and July, with an average rainfall of $855 \mathrm{~mm}$ per year. The average temperature is $25.3^{\circ} \mathrm{C}$ and average relative humidity of $79 \%$.

The properties were classified according to the production system, being specialized or semispecialized, considering the following criteria: 
- Farms specialized in milk production: those presenting cultivated pasture with management and pasture fertilization, division by grouping according to milk production, mechanized milking system, canalized or semi-canalized - with preand post-dipping practice - cleaning equipment and tanks with sanitizers, milk preservation in tank cooler in bulk, mastitis control practices, treatment of dry cows, treatment in cases of clinical mastitis;

- The properties that did not present this set of management practices were classified as semi- specialized.

The seasons of the year were divided into four: (1) - January to March; (2) - April to June; (3) - July to September; (4) - October to December.

Genotypes were divided into groups, classified as follows: (1) - 7/8 Holstein and Holstein (pure); (2) - Jersey (pure); (3) - 31/32 Holstein; (4) Brown Swiss and 31/32 Holstein; (5) - 3/4Girolando and 31/32 Holstein; (6) - 3/4Girolando.

Table 1 describes the properties in respect of production systems and genetic groups.

Table 1. Characterization of properties.

\begin{tabular}{ccc}
\hline Property & Production System & Genetic group \\
\hline 1 & Semi-specialized & Girolando $3 / 4$ \\
2 & Specialized & Holstein $31 / 32$ \\
3 & Specialized & Jersey (pure) \\
4 & Semi-specialized & $80 \%$ Girolando $3 / 4$ and $20 \%$ Holstein $31 / 32$ \\
5 & Specialized & $80 \%$ Holstein $7 / 8$ and $20 \%$ Holstein (pure) \\
6 & Semi-specialized & Girolando $3 / 4$ \\
7 & Semi-specialized & $70 \%$ Brown Swiss and $30 \%$ Holstein $31 / 32$ \\
8 & Specialized & Girolando $3 / 4$ \\
\hline
\end{tabular}

Collection of milk samples and laboratory analysis

Milk samples from the morning milking were collected monthly, directly from cooling tank. The samples were placed in plastic bottles of 40 $\mathrm{mL}$, homogenized and properly identified with the property number. Samples were kept at a temperature between 2 and $6{ }^{\circ} \mathrm{C}$ and sent to a Brazilian Milk Quality Network laboratory at the "Luiz de Queiroz" College of Agriculture (ESALQ/USP) for analysis of milk composition. The samples sent for SCC and TBC evaluation were stored in vials containing Bronopol ${ }^{\circledR}$ (2-bromo-2-nitro-1,3-propanediol) and Azidiol ${ }^{\circledR}$ preservatives, respectively.

Samples were submitted to analysis by infrared absorption (Bentley 2000 ${ }^{\circledR}$; Bentley Instruments Inc., Chasca MN, EUA) to determine protein, fat, lactose, total solids and casein levels. Milk urea nitrogen concentrations (MUN) were determined by the enzymatic spectrophotometric method (ChemSpeck $150^{\circledR}$; Bentley Instruments Inc., Chasca $\mathrm{MN}$, EUA). Somatic cell count was determined using electronic counting by Fourier transform infrared spectroscopy (FTIR), with MILKO SCAN FT+ equipment (FOSS ${ }^{\circledR}$, Denmark). Total bacterial count (TBC) was analyzed by flow cytometry using Bactocount $^{\circledR}$ equipment (Bentley Instruments Inc., Chasca MN, EUA).

\section{Data analysis}

Discrepant information due to sampling and/ or analytical error was deleted from the database. Initially there were 782 observations and after a 
final edition, we obtained 693 observations of fat, protein, lactose, total solids, non-fat dry extract and somatic cell count (SCC); 288 of casein and 582 of total bacterial count (TBC).

For statistical analysis, independent experimental variables were defined as: the production system (specialized and semispecialized), the genotype, year, time of year, and properties. For effect of the year were considered only 2010 and 2011. Data were tabulated and subsequently subjected to analysis of variance and the Fischer F-test. A mean comparison test was considered for the following criteria: the Tukey test was applied for up to $30 \%$ coefficient of variation and number of treatments $\leq 4$; the t-test was used for coefficients of variation greater than $30 \%$ and number of treatments $>4$. Both tests considered a level of 5\% probability for type I error. Statistical procedures were done through the Statistical Analysis System - SAS (1998) program.

The mathematical model used was:

$$
\mathrm{Y}_{\mathrm{ij}}=\mu+\mathrm{T}_{\mathrm{i}}+\mathrm{e}_{\mathrm{ij}}
$$

Where $\mathrm{Y}_{\mathrm{ij}}=$ observed value of the dependent variable; $\mu=$ overall average; $t_{i}=$ effect of the $i{ }^{\text {th }}$ treatment; $e_{i j}=$ experimental error. The treatment effects were: Production System (specialized or semi-specialized), $i=1$ and 2 ; Genetic grouping, $i=$ 1 to 6 ; Year, $i=1$ and 2; Season of the year, $i=1$ to 4; Farms, $i=1$ to 8 .

\section{Results and Discussion}

The results obtained for the variables of the eight herds are described in Table 2. For milk composition, the results detected were satisfactory and met the requirements of Normative Ruling 62 (BRASIL, 2011). This regulation seeks to standardize acceptable levels for hygienic composition and quality of milk in Brazil and is being gradually implemented throughout all regions of the country, according to their peculiarities. Other studies developed such as Sgarbieri (2005), Oliveira et al. (2011), and Ribeiro Neto et al. (2012) have shown that compliance with the requirement levels for milk composition is achievable, despite variations in the analyzed production systems.

Table 2. Chemical composition and sanitary conditions of the milk tank on the farms.

\begin{tabular}{|c|c|c|c|c|c|}
\hline Composition & $\mathrm{N}$ & Average & & SD & $\mathrm{CV} \%$ \\
\hline \multicolumn{6}{|c|}{ Milk composition } \\
\hline Fat $(\%)$ & 693 & 3.54 & \pm & 0.46 & 12.99 \\
\hline Protein $(\%)$ & 693 & 3.30 & \pm & 0.18 & 5.95 \\
\hline Lactose (\%) & 693 & 4.40 & \pm & 0.13 & 2.95 \\
\hline Total solids (\%) & 693 & 12.20 & \pm & 0.56 & 4.59 \\
\hline $\operatorname{DDE}(\%)$ & 693 & 8.66 & \pm & 0.18 & 2.07 \\
\hline MUN (mg/dL) & 693 & 13.21 & \pm & 3.74 & 28.31 \\
\hline Casein $(\%)$ & 288 & 2.60 & \pm & 0.64 & 24.61 \\
\hline PCAS ( $\%$ Prot $)$ & 288 & 76.68 & \pm & 5.95 & 7.80 \\
\hline \multicolumn{6}{|c|}{ Sanitary conditions } \\
\hline $\mathrm{SCC}(\mathrm{mil} / \mathrm{mL})$ & 693 & 589.90 & \pm & 367.50 & 62.30 \\
\hline TBC (CFU/mL) & 582 & 437.71 & \pm & 1048.96 & 239.64 \\
\hline
\end{tabular}

$\mathrm{N}=$ number of observations; $\mathrm{SD}=$ standard deviation; $\mathrm{CV}=$ coefficient of variation; $\mathrm{DDE}=$ defatted dry extract; $\mathrm{MUN}=$ milk urea nitrogen; PCAS = casein from total protein; $\mathrm{SCC}=$ Somatic cell count; $\mathrm{TBC}=$ total bacterial count. 
Somatic cell count (SCC) is a parameter which is usually used as a subclinical mastitis indicator (BERGLUND et al., 2007), and the average found in this study was higher than the limit recommended by the NR 62/2011 (BRASIL, 2011), equivalent to $500 \mathrm{x}$ thousand cells/mL for the region and study period.

High SCC values are associated with changes in milk composition, including milk changes in proteins and lipids, as well as its metabolites (SUNDEKILDE et al., 2013), leading to lower industrial efficiency of milk and a decrease in the life of the processed product (RUEGG, 2011). Also, due to the formation of scar tissue in the alveolar region replacing the secretory tissue, high SCC is also associated with production losses (BARBANO et al., 2006).

Cinar et al. (2015) concluded that high SCC negatively affects not only the yield, but also the composition and quality of milk, and suggests that monthly monitoring is the most effective method to monitor and evaluate changes in the production and quality of milk caused by the presence of mastitis in the herd.

In addition, for Holmberg et al. (2012) mastitis represents the biggest health problem in dairy cattle and there are several reasons to reduce the frequency of the disease. For dairy farmers, economic losses due to mastitis are associated with a reduction in milk production, milk disposal, conception rate and veterinary treatment costs.

Total bacterial count (TBC) in milk also showed a high average in relation to that regulated by NR 62/2011 (BRASIL, 2011), however, it is below the value referenced by Ribeiro Neto et al. (2012) for milk in the Northeast Region. Considering that the bacterial contamination of milk varies with the health of the mammary gland (ZADOKS et al., 2004), cleaning of the udder, teats, utensils, equipment surfaces and also with the storage conditions, this reiterates the importance of cleaning and sanitizing of all the parts that make up production logistics to improve the quality of raw milk (RANGEL et al., 2014). It is also worth mentioning that the microbiological quality of milk has a direct influence on the quality of the final product (QUEIROGA et al., 2007).

Brazilian dairy farming is characterized by marked heterogeneity in production systems, covering large, medium and small producers with different forms of organization. There are highly technical systems in milk production, which contrast rudimentary systems in the same geographical arrangement.

A comparative analysis for milk composition and the hygienic-sanitary aspects of specialized and semi-specialized systems defining the study methodology are presented in Table 3. All analyzed variables except for casein from total protein were influenced $(\mathrm{P}<0.05)$ by the production system used in the production unit. The literature reports that environmental factors such as the age at calving, calving month, lactation stage and the nutritional level of the animals all have an influence on milk composition (RESTLE et al., 2003; NORO et al., 2006). Therefore, knowing that these factors undergo great variation within each production unit, it is possible to understand the variation in milk composition shown in Table 3.

Simioni et al. (2013) studied the characterization of herds in the West of Santa Catarina (a state in the south of Brazil), and reported a trend of reduction in the levels of protein and fat as the level of productive specialization increased, with no clear trend in the other variables except for TBC, which showed significant reduction at the specialized level of production.

SCC and TBC values behaved similarly in both systems, with higher values on farms which had developed dairy farming with semi-specialized production systems $(p<0.05)$. Cavalcanti et al. (2010) stated that the use of appropriate hygiene techniques in milking is a strategy for improving the bacteriological quality of milk. The use of 
alkaline and acid cleaners in addition to sanitizers is associated with bacterial count below 100 thousand $\mathrm{CFU} / \mathrm{ml}$, while the use of only one or no product is associated with higher counts than 500 thousand CFU/mL (ARCURI et al., 2006). These authors concluded that adopting proper cleaning procedures of milking and milk storage equipment helps to reduce the bacterial count. This fact corroborates what was found in this study; it is possible to infer that the specialized milk production farms adopted more efficient cleaning procedures for milking and the instruments involved in the production and storage processes.

Table 3. Chemical composition (in \%) and sanitary quality of milk according to the production system adopted on the farm.

\begin{tabular}{|c|c|c|c|}
\hline \multirow{2}{*}{ Composition } & \multicolumn{2}{|c|}{ Farms } & \multirow{2}{*}{$\mathrm{CV} \%$} \\
\hline & Specialized & Semi-specialized & \\
\hline \multicolumn{4}{|c|}{ Milk composition } \\
\hline Fat (\%) & $3.65^{\mathrm{a}}$ & $3.43^{\mathrm{b}}$ & 12.77 \\
\hline Protein $(\%)$ & $3.38^{\mathrm{a}}$ & $3.22^{\mathrm{b}}$ & 5.05 \\
\hline Lactose $(\%)$ & $4.36^{\mathrm{b}}$ & $4.43^{\mathrm{a}}$ & 2.93 \\
\hline Total solids (\%) & $12.32^{\mathrm{a}}$ & $12.07^{\mathrm{b}}$ & 4.46 \\
\hline DDE $(\%)$ & $8.68^{\mathrm{a}}$ & $8.64^{\mathrm{b}}$ & 2.10 \\
\hline MUN (mg/dL) & $14.04^{\mathrm{a}}$ & $12.36^{\mathrm{b}}$ & 27.61 \\
\hline Casein $(\%)$ & $2.70^{\mathrm{a}}$ & $2.49^{\mathrm{b}}$ & 24.33 \\
\hline PCAS (\% Prot) & $76.30^{\mathrm{a}}$ & $77.10^{\mathrm{a}}$ & 7.76 \\
\hline \multicolumn{4}{|c|}{ Sanitary conditions } \\
\hline $\mathrm{SCC}(\mathrm{mil} \mathrm{CS} / \mathrm{mL})$ & $561.73^{\mathrm{b}}$ & $618.63^{\mathrm{a}}$ & 62.16 \\
\hline TBC (mil CFU/mL) & $182.27^{\mathrm{b}}$ & $703.91^{\mathrm{a}}$ & 232.31 \\
\hline
\end{tabular}

${ }^{\mathrm{a}, \mathrm{b}}$ Different letters in the same line indicate that there is a statistical difference by Tukey test at a significance level of $5 \%$; $\mathrm{CV}=$ coefficient of variation; DDE = defatted dry extract; $\mathrm{MUN}=$ milk urea nitrogen; $\mathrm{PCAS}=$ casein from total protein; $\mathrm{SCC}=\mathrm{Somatic}$ cell count; $\mathrm{TBC}=$ total bacterial count.

The results of the chemical composition and sanitary quality of milk in accordance with the year are described in Table 4. As described by Ribas et al. (2015), the effect of the year on the quality characteristics reflects a complex of influences to which animals are subjected during the year, such as differences in climate, management, health and nutrition.

Lower fat levels were verified in 2010. It is known that fat content is strongly influenced by genotype and by environmental factors, and is the most variable component of dairy species and breeds. Usually, normal fat content has been linked to good rumen conditions, promoted by ingesting levels of good quality fiber in the diet, which provides increased acetate production (VAN SOEST, 1994). However, in addition to these factors, it is noted that the amount of milk produced also has a direct influence on this parameter, so that the fat percentage is inversely proportional to the amount of milk produced (ARAÚJO et al., 2012). Therefore, it is possible that this would explain the observed difference for milk fat content, since rainfall shortages in 2011 caused severe quantitative and qualitative reduction in food resources, culminating in a reduction in milk production. 
Table 4. Chemical composition (in \%), sanitary and hygienic quality of milk according to the year.

\begin{tabular}{lccc}
\hline \multirow{2}{*}{ Composition } & \multicolumn{2}{c}{ Year } & CV (\%) \\
\cline { 2 - 3 } & 2010 & 2011 & \\
Fat (\%) & \multicolumn{2}{c}{ Milk composition } & 12.79 \\
Protein (\%) & $3.44^{\mathrm{b}}$ & $3.63^{\mathrm{a}}$ & 5.56 \\
Lactose (\%) & $3.30^{\mathrm{a}}$ & $3.29^{\mathrm{a}}$ & 3.00 \\
Total solids (\%) & $4.43^{\mathrm{a}}$ & $4.37^{\mathrm{b}}$ & 4.54 \\
DDE (\%) & $12.13^{\mathrm{a}}$ & $12.25^{\mathrm{a}}$ & 2.06 \\
MUN (mg/dL) & $8.70^{\mathrm{a}}$ & $8.61^{\mathrm{b}}$ & 28.26 \\
Casein (\%) & $13.14^{\mathrm{a}}$ & $13.43^{\mathrm{a}}$ & 6.26 \\
PCAS (\%Prot) & $2.73^{\mathrm{a}}$ & $2.54^{\mathrm{b}}$ & 1.42 \\
\hline & $70.00^{\mathrm{b}}$ & $77.36^{\mathrm{a}}$ & \\
SCC (mil/mL) & \multicolumn{2}{c}{ Sanitary conditions } \\
TBC (CFU/mL) & $509.75^{\mathrm{b}}$ & $649.07^{\mathrm{a}}$ & 60.58 \\
\hline
\end{tabular}

a,b Different letters in the same line indicate that there is a statistical difference by Tukey test at a significance level of $5 \%$; $\mathrm{CV}=$ coefficient of variation; $\mathrm{DDE}=$ defatted dry extract; $\mathrm{MUN}=$ milk urea nitrogen; $\mathrm{PCAS}=$ casein from total protein; $\mathrm{SCC}=$ Somatic cell count; $\mathrm{TBC}=$ total bacterial count.

High SCC levels lead to several changes in milk composition, not only affecting its quality, but also its composition (CINAR et al., 2015). This is because they alter the permeability of blood vessel glands and decrease the secretion of milk components synthesized in the mammary gland (protein, fat and lactose) by the direct action of pathogens or enzymes on the secreted components inside the gland (MACHADO et al., 2000). An interesting aspect is that the lactose metabolization by mesophilic bacteria which colonize the milk in the cooling tank results in the formation of organic acids which makes the milk less stable to heat processing. High SCC can also negatively interfere with the synthesis of casein due to the destruction of secretory parenchyma and less casein secretion by mammary gland cells (LITWIŃCZUK et al., 2011).

The high values of SCC and TBC observed could be related to most - if not exclusively to - directing financial resources to purchase food during the dry season that characterized the year of 2011. The rainfall shortage severely suppressed forage resources on farms, as well as causing an increase in raw material prices used in animal feed, which may have triggered lower product purchasing power used in the hygiene of milking and instruments.

Lopes et al. (2011) claim that the cost acquiring pre- and post-dipping solutions, acids and alkaline detergents, paper towels, disinfectants and other products used for milking hygiene consists of a representative percentage within the effective operating expenses. Also, Cicconi-Hogan et al. (2013) stressed the importance of using solutions and detergents in the prevention and control of mastitis in stating that organic farms are reluctant to make use of certain industrial products for milking hygiene, and therefore contamination by Staphilococcus aureus is elevated.

The analysis results of the seasonal effect in relation to the physico-chemical composition and quality of milk are described in Table 5. With the exception of casein, all the constituents of milk had lower values in the dry season (seasons 3 and 4). Gonzalez et al. (2004), Simioni et al. (2014) and Vargas et al. (2015) also found variation in bovine milk composition according to the months of the year, and pointed out low quantitative 
and qualitative supply of forage as the probable cause that occurs at some periods of the year. The reduction in levels of fat, protein and total solids, which are substantially influenced by nutritional management (ROSA et al., 2012), reaffirm this effect.

Table 5. Chemical composition (in \%) and sanitary quality of milk according to season of the year.

\begin{tabular}{|c|c|c|c|c|c|}
\hline \multirow{2}{*}{ Composition \% } & \multicolumn{4}{|c|}{ Seasons } & \multirow{2}{*}{$\mathrm{CV} \%$} \\
\hline & 1 & 2 & 3 & 4 & \\
\hline \multicolumn{6}{|c|}{ Chemical composition } \\
\hline Fat $(\%)$ & $3.51^{\mathrm{b}}$ & $3.65^{\mathrm{a}}$ & $3.55^{\mathrm{ab}}$ & $3.42^{\mathrm{b}}$ & 13.02 \\
\hline Protein $(\%)$ & $3.35^{\mathrm{a}}$ & $3.30^{\mathrm{b}}$ & $3.29^{\mathrm{b}}$ & $3.26^{\mathrm{b}}$ & 5.53 \\
\hline Lactose $(\%)$ & $4.39^{\mathrm{b}}$ & $4.38^{\mathrm{b}}$ & $4.43^{\mathrm{a}}$ & $4.38^{\mathrm{b}}$ & 3.04 \\
\hline Total solids (\%) & $12.22^{\mathrm{ab}}$ & $12.28^{\mathrm{a}}$ & $12.22^{\mathrm{ab}}$ & $12.08^{\mathrm{b}}$ & 4.55 \\
\hline $\operatorname{DDE}(\%)$ & $8.71^{\mathrm{a}}$ & $8.63^{\mathrm{bc}}$ & $8.67^{\mathrm{ab}}$ & $8.60^{\mathrm{c}}$ & 2.05 \\
\hline MUN (mg/dL) & $13.15^{\mathrm{a}}$ & $13.83^{\mathrm{a}}$ & $14.04^{\mathrm{a}}$ & $11.75^{\mathrm{b}}$ & 27.63 \\
\hline Casein (\%) & $2.76^{\mathrm{a}}$ & $2.56^{\mathrm{a}}$ & $2.50^{\mathrm{a}}$ & $2.54^{\mathrm{a}}$ & 24.45 \\
\hline PCAS (\% Prot) & $74.66^{\mathrm{b}}$ & $78.16^{\mathrm{a}}$ & $76.70^{\mathrm{ab}}$ & $77.02^{\mathrm{ab}}$ & 7.60 \\
\hline \multicolumn{6}{|c|}{ Sanitary conditions } \\
\hline $\mathrm{SCC}(\mathrm{mil} / \mathrm{mL})$ & $603.70^{\mathrm{a}}$ & $640.13^{\mathrm{a}}$ & $554.51^{\mathrm{a}}$ & $564.89^{\mathrm{a}}$ & 62.19 \\
\hline TBC (CFU/mL) & $581.70^{\mathrm{a}}$ & $586.80^{\mathrm{a}}$ & $167.40^{\mathrm{b}}$ & $418.1^{\mathrm{ab}}$ & 236.88 \\
\hline
\end{tabular}

a,b Different letters in the same line indicate that there is statistical difference by Tukey test at a significance level of $5 \%$; $\mathrm{CV}=$ coefficient of variation; DDE = defatted dry extract; $\mathrm{MUN}=$ urea nitrogen; PCAS = casein from total protein; SCC $=$ Somatic cell count; $\mathrm{TBC}=$ total bacterial count; Season 1 = January to March; Season 2 = April to June; Season 3 = July to September; Season $4=$ October to December.

SCC and TBC showed higher values in seasons 1 and 2, which are considered rainy periods. It is recurrent in the literature that increases in levels of SCC and TBC transpire in the rainy season, mainly due to increase in soil attached to the animal that hinders the sterilization of the udder and can colonize both the organ as well as the milk itself, compromising quality (RHODA; PANTOJA, 2012).

The findings of this study corroborate the ones obtained by Magalhães et al. (2006), which found lower values for SCC in spring when rainfall is generally lower, which according to our study corresponds to seasons 3 and 4, covering the months from July to December. In monthly monitoring conducted by the USDA (2015) of US cooling tanks, it was found that the peak SCC values occurred in summer (June to September), when there are high temperatures, increased humidity and stress on cows, providing more favorable conditions for bacterial growth.

The analysis results of the effect of genotype with respect to physico-chemical composition and milk quality are described in Table 6 .

The chemical composition of milk varied with genotypes, corroborating Giovannini et al. (2014), who associated the production of fat to animal genetics. Higher fat and protein content were observed for milk produced by the compound group of Jersey cows, reaffirming the ability of animals of this breed to produce milk with higher levels of fat and protein.

Other changes in milk composition may be explained by the diluting effect of the milk components in the produced milk volume, in fact, high levels of production lead to lower fat and 
protein content in milk (GALVÃO JÚNIOR et al., 2010). In evaluating crossbred dairy cows, Martins et al. (2012) reported the influence of genetic composition and production level on milk composition, particularly on the levels of fat, protein and total solids.

Table 6. Effect of genotype on the chemical composition (in \%) and sanitary quality of milk.

\begin{tabular}{|c|c|c|c|c|c|c|c|}
\hline \multirow{2}{*}{ Composition } & \multicolumn{6}{|c|}{ Genotype } & \multirow{2}{*}{$\mathrm{CV} \%$} \\
\hline & 1 & 2 & 3 & 4 & 5 & 6 & \\
\hline \multicolumn{8}{|c|}{ Milk composition } \\
\hline Fat $(\%)$ & $3.10^{\mathrm{d}}$ & $4.39^{\mathrm{a}}$ & $3.17^{\mathrm{d}}$ & $3.52^{\mathrm{bc}}$ & $3.61^{\mathrm{b}}$ & $3.44^{\mathrm{c}}$ & 7.85 \\
\hline Protein $(\%)$ & $3.20^{\mathrm{d}}$ & $3.64^{\mathrm{a}}$ & $3.13^{\mathrm{e}}$ & $3.34^{\mathrm{b}}$ & $3.26^{\mathrm{c}}$ & $3.26^{\mathrm{c}}$ & 3.55 \\
\hline Lactose (\%) & $4.43^{\mathrm{bc}}$ & $4.24^{\mathrm{e}}$ & $4.48^{\mathrm{ab}}$ & $3.36^{\mathrm{d}}$ & $4.40^{\mathrm{c}}$ & $4.49^{\mathrm{a}}$ & 2.59 \\
\hline Total solids (\%) & $11.67^{\mathrm{c}}$ & $13.24^{\mathrm{a}}$ & $11.77^{\mathrm{c}}$ & $12.16^{\mathrm{b}}$ & $12.25^{\mathrm{b}}$ & $12.18^{\mathrm{b}}$ & 2.55 \\
\hline $\operatorname{DDE}(\%)$ & $8.57^{\mathrm{d}}$ & $8.85^{\mathrm{a}}$ & $8.60^{\mathrm{cd}}$ & $8.64^{\mathrm{c}}$ & $8.63^{\mathrm{cd}}$ & $8.74^{\mathrm{b}}$ & 1.89 \\
\hline MUN (mg/dL) & $16.33^{\mathrm{a}}$ & $10.98^{\mathrm{c}}$ & $14.30^{\mathrm{b}}$ & $13.43^{\mathrm{b}}$ & $11.57^{\mathrm{c}}$ & $13.80^{\mathrm{b}}$ & 25.40 \\
\hline Casein $(\%)$ & $2.84^{\mathrm{a}}$ & $2.84^{\mathrm{a}}$ & $2.38^{\mathrm{b}}$ & $2.57^{\mathrm{ab}}$ & $2.50^{\mathrm{ab}}$ & $2.55^{\mathrm{ab}}$ & 24.06 \\
\hline PCAS (\% Prot) & $73.45^{\mathrm{b}}$ & $77.73^{\mathrm{a}}$ & $76.95^{\mathrm{ab}}$ & $77.12^{\mathrm{ab}}$ & $77.20^{\mathrm{a}}$ & $77.23^{\mathrm{a}}$ & 7.63 \\
\hline \multicolumn{8}{|c|}{ Sanitary conditions } \\
\hline $\mathrm{SCC}(\mathrm{mil} / \mathrm{mL})$ & $705.75^{\mathrm{b}}$ & $543.24^{\mathrm{cd}}$ & $176.7^{\mathrm{e}}$ & $828.84^{\mathrm{a}}$ & $609.74^{\mathrm{bc}}$ & $427.6^{\mathrm{d}}$ & 51.70 \\
\hline $\mathrm{TBC}(\mathrm{CFU} / \mathrm{mL})$ & $174.9^{\mathrm{bcd}}$ & $142.9^{\text {cd }}$ & $578.2^{\mathrm{abc}}$ & $618^{\mathrm{ab}}$ & $643.9^{\mathrm{a}}$ & $37.4^{\mathrm{d}}$ & 234.2 \\
\hline
\end{tabular}

The analysis of physical and chemical composition of genotype 5 milk (Girolando $3 / 4$ and Holstein - pure) was, in a way, compromised by the fact that milk coming from two genetic groups that produce milk with different compositions had been mixed in the same tank. Animals with higher percentage of zebu blood tend to produce more concentrated milk, while animals with the highest percentage of Holstein blood produce milk with lower levels of fat, protein and total solids due to its higher production.

\section{Conclusion}

The chemical composition of milk has met the legal and market requirements, demonstrating significant positive results towards specialized production systems which can be converted into economic advantage due to better production yield and/or surplus. However, it also showed significant variations throughout the year and according to the genetic group of the herd; aspects that deserve to be considered in seeking production activity improvements and specialization.

Regarding the aspect of hygiene and sanitation, it is worrisome that neither specialized nor semi-specialized systems met the current legal requirements. These results portray the need for a greater focus on the entities involved in the sector, as well as on producers to achieve an adequate program of monitoring management practices related to this criterion. 


\section{References}

ANDRADE, K. D.; RANGEL, A. H. do N.; ARAÚJO, V. M.; MEDEIROS, H. R.; BEZERRA, K. C.; BEZERRIL, R. F.; LIMA JÚNIOR, D. M. Qualidade do leite bovino nas diferentes estações do ano no estado do Rio Grande do Norte. Revista Brasileira de Ciências Veterinárias, Niterói, v. 21, n. 3, p. 213-216, jul./set. 2014.

ARAÚJO, V. M.; RANGEL, A. H. do N.; BEZERRA, K. C.; ANDRADE, K. D.; GUERRA, M. G. Avaliação de testes rápidos para análise da contagem de células somáticas de leite cru de tanques. Acta Veterinária Brasílica, Mossoró, v. 6, n. 4, p. 321-324, jul./set. 2012.

ARCURI, E. F.; BRITO, M. A. V. P.; BRITO, J. R. F.; PINTO, S. M.; ANGÊLO, F. F.; SOUZA, G. N. Qualidade microbiológica do leite refrigerado nas fazendas. Arquivo Brasileiro de Medicina Veterinária e Zootecnia, Belo Horizonte, v. 58, n. 3, p. 440-446, jun. 2006.

BARBANO, D. M.; MA, Y.; SANTOS, M. V. Influence of raw milk quality on fluid milk shelf life 1, 2. Journal of Dairy Science, Champaign, v. 89, p. E15-E19, mar. 2006. Supplement.

BERGLUND, I.; PETTERSSON, G.; OSTENSSON, K.; SVERNNESTEM-SJAUNJA, K. Quarter milking for improved detection of increase SCC. Reproduction in Domestic Animals, Malden, v. 42, n. 4, p. 427-432, apr. 2007.

BRASIL. Ministério da Agricultura, Pecuária e Abastecimento. Instrução Normativa $\mathrm{n}^{\circ} 62$, de 29 de dezembro de 2011. Diário Oficial [da] União, Brasília, DF, 30 de dez. 2011. Seção 1, p. 24.

CAVALCANTI, E. R. C.; CAVALCANTI, M. A. R.; SOUZA, W. J. de; ARAÚJO, D. G. de. Avaliação microbiológica em ordenhadeira mecânica antes e após adoção de procedimento orientado de higienização. Revista Brasileira de Ciência Veterinária, Niterói, v. 17, n. 1, p. 3-6, jan./mar. 2010.

CICCONI-HOGAN, K. M.; GAMROTH, M.; RICHERT, R.; RUEGG, P. L.; STIGLBAUER, K. E.; SCHUKKEN, Y. H. Associations of risk factors with somatic cell count in bulk tank milk on organic and conventional dairy farms in the United States. Journal of Dairy Science, Champaign, v. 96, n. 6, p. 3689-3702, jun. 2013.

CINAR, M.; SERBESTER, U.; CEYHAN, A.; GORGULU, M. Effect of somatic cell count on milk yield and composition of first and second lactation dairy cows. Italian Journal of Animal Science, Provincia di Viterbo, v. 14, n. 1, p. 105-108, jan. 2015.
GALVÃO JÚNIOR, J. G. B.; RANGEL, A. H. do N.; MEDEIROS, H. R.; SILVA, J. B. A.; AGUIAR, E. M.; MADRUGA, R. C.; LIMA JÚNIOR, D. M. Efeito da produção diária e da ordem de parto na composição físico-química do leite de vacas de raças zebuínas. Acta veterinária Brasilica, Mossoró, v. 4, n. 1, p. 25-30, jan./ mar. 2010.

GIOVANNINI, C. I.; QUEIROZ, E. O.; CONDE, I. R. S.; OLIVEIRA JÚNIOR, J. A.; NEVES, R. B. S.; SANTOS, P. A. Influence of milk production system on the proximate composition, Dry defatted extract and somatic cell count. Revista Brasileira de Higiene e Sanidade Animal, Fortaleza, v. 8, n. 3, p. 200-206, ago. 2014.

GONZALEZ, H. L.; FISCHER, V.; RIBEIRO, M. E. R.; GOMES, J. F.; STUMPF, J. R. W.; SILVA, M. A. Avaliação da qualidade do leite na bacia leiteira de Pelotas, RS: efeito dos meses do ano. Revista Brasileira de Zootecnia, Viçosa, MG, v. 33, n. 6, p. 1531-1543, nov. 2004.

HOLMBERG, M.; FIKSE, W. F.; ANDERSONEKLUND, L.; ARTURSSON, K.; LUNDÉN, A. Genetic analyses of pathogen-specific mastitis. Journal of Breeding and Genetics, Malden, v. 129, n. 2, p. 129-137, apr. 2012.

LITWIŃCZUK, Z.; KRÓL, J.; BRODZIAK, A.; BARLOWSKA, J. Changes of protein content and its fractions in bovine milk from different cow breeds subject to somatic cell count. Journal of Dairy Science, Champaign, v. 94, n. 2, p. 684-691, mar. 2011.

LOPES, A. M.; SANTOS, G.; RESENDE, M. C.; CARVALHO, F. M.; CARDOSO, M. G. Estudo da rentabilidade de sistemas de produção de leite no município de Nazareno, MG. Ciência Animal Brasileira, Goiânia, v. 12, n. 1, p. 58-69, jan./mar. 2011.

MACHADO, P. F.; PEREIRA, A. R.; SARRIES, G. A. Composição do leite de tanques de rebanhos brasileiros distribuídos segundo sua contagem de células somáticas. Revista Brasileira de Zootecnia, Viçosa, MG, v. 29, n. 6, p. 1883-1886, nov. 2000.

MAGALHÃES, H. R.; FARO, L. E.; CARDOSO, V. L.; PAZ, C. C.; CASSOLI, L. D.; MACHADO, P. F. Influência de fatores de ambiente sobre a contagem de células somáticas e sua relação com perdas na produção de leite de vacas da raça Holandesa. Revista Brasileira de Zootecnia, Viçosa, MG, v. 35, n. 2, p. 415-421, mar. 2006.

MAIA, G. B. D. S.; PINTO, A. D. R.; MARQUES, C. Y. T.; ROITMAN, F. B.; LYRA, D. D. Produção leiteira no Brasil. BNDES Setorial, Rio de Janeiro, v. 2, n. 37, p. 371-398, mar. 2013. 
MARTINS, M. E. P.; NICOLAU, E. S.; MESQUITA, A. J. de; NEVES, R. B. S.; ARRUDA, M. L. T. Qualidade de leite cru produzido e armazenado em tanques de expansão no estado de Goiás. Ciência Animal Brasileira, Goiânia, v. 9, n. 4, p. 1152-1158, out. 2008.

MARTINS, S. C. S. G.; ROCHA JÚNIOR, V. R.; CALDEIRA, L. A.; REIS, S. T.; BARROS, I. C.; OLIVEIRA, J. A.; SANTOS, J. F.; SILVA, G. W. V. Rendimento, composição e análise sensorial do queijo minas frescal fabricado com leite de vacas mestiças alimentadas com diferentes volumosos. Revista Brasileira de Zootecnia, Viçosa, MG, v. 41, n. 4, p. 9931003, jul. 2012.

NORO, G.; GONZÁLEZ, F. H. D.; CAMPOS, R.; DÜRR, J. W. Fatores ambientais que afetam a produção e a composição do leite em rebanhos assistidos por cooperativas no Rio Grande do Sul. Revista Brasileira de Zootecnia, Viçosa, MG, v. 35, n. 3, p. 1129-1135, maio 2006.

OLIVEIRA, A. S.; CUNHA, D. N. F. V.; CAMPOS, J. M. S.; VALE, S. M. L. R.; ASSIS, A. J. Identificação e quantificação de indicadores-referência de sistemas de produção de leite. Revista Brasileira Zootecnia, Viçosa, MG, v. 36, n. 2, p. 507-516, mar. 2007.

OLIVEIRA, C. J. B.; LOPES JÚNIOR, W. D.; QUEIROGA, R. C. R. E.; GIVISIEZ, P. E. N.; AZEVEDO, P. S.; PEREIRA, W. E.; GEBREYES, W. A. Risk factors associated with selected indicators of milk quality in semiarid northeastern Brazil. Journal of Dairy Science, Champaign, v. 94, n. 6, p. 3166-3175, nov. 2011.

QUEIROGA, R. C. R. E.; COSTA, R. G.; BARRETO, T. M.; BISCONTINI, A. N. D. M.; MADRUGA, M. S.; RICARDO, A.; SCHULER, P. Influência do manejo do rebanho, das condições higiênicas da ordenha e da fase de lactação na composição química do leite de cabras Saanen. Revista Brasileira de Zootecnia, Viçosa, MG, v. 36, n. 2, p. 430-437, mar. 2007.

RANGEL, A. H. do N.; ARAÚJO, V. M.; BEZERRA, K. C.; BEZERRIL, R. F.; GUERRA, M. G.; LIMA JÚNIOR, D. M.; MOURA, E. O.; OLIVEIRA, N. A. Processo de higienização nos equipamentos de ordenha em propriedades leiteiras. Acta Veterinaria Brasilica, Mossoró, v. 8, n. 2, p. 107-112, mar. 2014.

RESTLE, J.; PACHECO, P. S.; MOLETTA, J. L.; BRONDANI, I. L.; CERDÓTES, L. Grupo genético e nível nutricional pós-parto na produção e composição do leite de vacas de corte. Revista Brasileira de Zootecnia, Viçosa, MG, v. 32, n. 3, p. 585-597, maio 2003.
RHODA, D. A.; PANTOJA, J. C. F. Using mastitis records and somatic cell count data. Veterinary Clinics of North America: Food Animal Practice, Maryland Heights, v. 28, n. 2, p. 347-362, ago. 2012.

RIBEIRO NETO, A. C.; BARBOSA, S. B. P.; JATOBÁ, R. B.; SILVA, A. M.; SILVA, C. X.; SILVA, M. J. A.; SANTORO, K. R. Qualidade do leite cru refrigerado sob inspeção federal na região Nordeste. Arquivo Brasileiro de Medicina Veterinária e Zootecnia, Belo Horizonte, v. 64, n. 5, p. 1343-1351, jun. 2012.

ROMA JÚNIOR, L. C.; MONTOYA, J. F.; MARTINS, T. T.; CASSOLI, L. D.; MACHADO, P. F. Sazonalidade do teor de proteína e outros componentes do leite e sua relação com programa de pagamento por qualidade. Arquivo Brasileiro de Medicina Veterinária e Zootecnia, Belo Horizonte, v. 61, n. 6, p. 1411-1418, ago. 2009.

RIBAS, N. P.; HORST, J. A.; ANDRADE, U. V. C.; PACHECO, H. A.; REGONATO, A. Porcentagem de lactose em amostras de leite de tanque no estado do Paraná. Archives of Veterinary Science, Curitiba, v. 20, n. 3, p. 48-58, jan. 2015.

ROSA, D. C.; TRENTIN, J. M.; PESSOA, G. A.; SILVA, C. A. M.; RUBIN, M. I. B. Qualidade do leite em amostras individuais e de tanque de vacas leiteiras. Revista Arquivos do Instituto de Biologia, São Paulo, v. 79, n. 4, p. 485-493, jul. 2012.

RUEGG, P. L. Managing mastitis and producing high quality milk. In: RISCO, C.; MELENDEZ, P. (Ed.). Dairy cattle production medicine. Ames, Iowa: WileyBlackwell Publishing Ltd, 2011. p. 207-232.

SGARBIERI, V. C. Revisão: propriedades estruturais e físico-químicas das proteínas do leite. Brazilian Journal of Food Technology, Campinas, v. 8, n. 1, p. 43-56, jan. 2005.

SIMIONI, F. J.; BARETTA, C. R. D. M.; STEFANI, L. M.; LOPES, L. S.; TIZZIANI, T. Qualidade do leite proveniente de propriedades com diferentes níveis de especialização. Semina: Ciências Agrárias, Londrina, v. 34, n. 4, p. 1901-1912, jul./ago. 2013.

SIMIONI, F. J.; LOPES, L. S.; NESPOLO, C. R.; STEFANI, L. M.; BORDIGNON, R.; BITTELBRUN, M. S. Influência da época do ano sobre a composição físico-química e microbiológica do leite na região Oeste de Santa Catarina. Semina: Ciências Agrárias, Londrina, v. 35, n. 4, p. 2033-2046, jul./ago. 2014.

STATISTICAL ANALYSIS SYSTEM - SAS/STAT User's guide. $6^{\text {th }}$ ed. Cary, NC: SAS Institute, 1998. 
SUNDEKILDE, U. K.; POULSEN, N. A.; LARSEN, L. B.; BERTRAM, H. C. Nuclear magnetic resonance metabonomics reveals strong association between milk metabolites and somatic cell count in bovine milk. Journal of Dairy Science, Champaign, v. 96, n. 1, p. 290299, jan. 2013.

TAKAHASHI, F. H.; CASSOLI, L. D.; ZAMPAR, A.; MACHADO, P. F. Variação e monitoramento da qualidade do leite através do controle estatístico de processos. Ciência Animal Brasileira, Goiânia, v. 13, n. 1, p. 99-107, jan. 2012.

UNITED STATES DEPARTMENT OF AGRICULTURE - USDA. Animal and Plant Health Inspection Service's Center for Epidemiology and Animal Health. Determining U.S. Milk Quality Using Bulk-Tank Somatic Cell Counts. Fort Collins: APHIS, 2014. Available at: <http://nahms. aphis.usda.gov>. Accessed at: 4 ago 2015.
VAN SOEST, P. J. Nutritional ecology of the ruminant. $2^{\text {th }}$ ed. Ithaca: Cornell, 1994. $476 \mathrm{p}$.

VARGAS, D. P. de; NÖRNBERG, J. L.; SCHEIBLER, R. B.; SCHAFHAUSER JUNIOR, J.; RIZZO, F. A.; WAGNER, R. Qualidade e potencial nutracêutico do leite bovino em diferentes sistemas de produção e estações do ano. Pesquisa Agropecuária Brasileira, Brasília, v. 50, n. 12, p. 1208-1219, dez. 2015.

ZADOKS, R. N.; GONZALEZ, R. N.; BOOR, K. J.; SCHUKKEN, Y. H. Mastitis-causing Streptococci are important contributors to bacterial counts in raw bulk tank milk. Journal Food Protection, Des Moines, v. 67, n. 12, p. 2644-2650, dez. 2004. 